\title{
Social Shame Versus Private Shame: A Real Dichotomy?
}

\author{
Alba Montes SÁnchez
}

\section{Introduction*}

In the past few decades, shame has attracted much attention as a topic of study for psychology, philosophy, cultural studies, and so on, where shame has generally been understood as an emotion that bears importantly on our sense of self and has crucial implications for ethics. ${ }^{1}$ Those two issues, the form of selfhood that appears in shame and the role shame plays in ethics, are connected in crucial ways, and this connection has always been at play in the debates, although it is not always made explicit in the literature. In this paper I will be focusing on the specific question of whether shame is social or private, which on a first approach has been taken as an inquiry into the ownership of the norms that inform the self-assessment that takes place in this emotion, but which I will try to recast in different, hopefully more illuminating, terms. This question cuts across issues of selfhood and ethics, and has implications for both, although the ways in which this debate is framed will lead me to talk more about selfhood. But the concern in the background pertains to the ethical role of shame: does shame contribute positively to ethics or does it hinder it? Or should we simply say it can go both ways? Do we need shame to be moral persons?

As this latter question suggests, the ethical puzzle cannot be (and has not been) addressed in complete isolation from the issue of selfhood. Indeed, in my view, part of the disagreement on 
the question of whether shame is social or non-social is based on ethical and even political motivations: on assumptions about the kind of subjects we have to be in order to be moral, or about the political-communitarian versus liberal-implications of ascribing importance to shame in our ethical lives. ${ }^{2}$ Obviously, doing justice to those questions would require at least a whole monograph, and I will not even attempt to go into them here, but they can help clarify what is at stake in the discussion I will be tackling. Deciding whether we take shame to be social or private, or in a certain sense both (as I will be defending), and clarifying what we mean by this, will have an impact on the ethical status we assign to it and on the weight we will give to considerations connected to shame when we think about ourselves and about ethics.

This paper starts by briefly framing the question in the context of the wider debate on the ethical status of shame. It then casts a look at some basic features of this emotion and at the most common elements of its definitions. It goes on to examine the claim that the object of shame is the self of the person ashamed, looking at shame felt for others as an indication that the self has no clear limits that can be established from within, but rather is partially constituted by views from without, as we ourselves actually recognise in these blurry cases of other-directed shame. I then sum up the allegedly mainstream view of shame as social, followed by Julien A. Deonna, Raffaele Rodogno, and Fabrice Teroni's criticism of it and their account of shame as non-social, or private. ${ }^{3}$ I will argue that their account of the non-social character of shame simply in terms of ownership of norms fails to address the truly private aspect of this emotion, and I will offer an alternative interpretation of what is private and social in shame, based on a phenomenological approach to selfhood and to this emotion. This will give me a basis to conclude that there is no dichotomous opposition: shame, as an experience of self-revelation and self-exposure, requires 
the social and the private to take place, and thus can only appear in the intermediate spaces between them.

It should be noted from the start that I am not aiming here at an analysis of the conventions that guide our perceptions of the shameful, a description and discussion of the typical causes and situations that give rise to shame in a particular cultural context. Rather, I am aiming at a philosophical account of the conditions of possibility of such conventions, i.e., of the structures of the self that make them and their workings possible. In that endeavour, I will be relying on insights and accounts from different disciplines (mainly philosophy, psychology, and literature) and very heterogeneous sources that, in my view, can illuminate one or the other aspect of shame. The implication is not that shame has been a perfectly unitary and stable phenomenon throughout history (it has not), nor that different approaches and narratives are interested in it in the same ways. Quite the opposite. The value is precisely to be found in heterogeneity. The complexity and variety of emotional phenomena is such that adequate accounts of them can greatly benefit from taking into consideration multiple perspectives. Furthermore, the idea that the core of shame is linked to the structures of human selfhood, an idea that I am endorsing, can gain support by showing that some constitutive elements remain stable despite changes in the conventions of the shameful.

\section{Framing the Question: The Ethical Role of Shame}

The debate on the ethical role of shame has run roughly as follows. According to some versions of shame (of Aristotelian inspiration), this emotion is essential and positive for morality. As Myles Burnyeat puts it, in this interpretation shame is the "semi-virtue of the learner": an emotion that points towards virtue, by signalling our mistakes and thus allowing us to learn from 
them (Burnyeat 78-79). As Adriaan van Heerden sums up, "[t]hose who feel ashamed of their mistakes have the potential to learn from them, but to make a mistake and not to feel ashamed is the final proof of a wicked character" (van Heerden 47). And we don't need to be ancient Greeks to see things roughly this way: nowadays shamelessness is still generally equated to indignity and immorality, which seems to indicate that shame is morally valuable, at least sometimes. The problem is that many instances of shame seem to go against this view, because this emotion is often unconnected to ethics: one can feel ashamed of one's origins or one's personal appearance, as teenagers typically are, for instance. On other occasions, the desire to hide our shame can lead us to immoral actions, so its connection to commendable behaviour and ethical learning is less than clear.

Some other accounts cast shame as primitive, antisocial, and maladaptive in our current Western societies, occasionally going as far as saying that we would be better off without it. A particularly forceful example of this kind of view can be found in the work of psychologist June Price Tangney, but many other authors, such as anthropologist Ruth Benedict and historian of ideas Ruth Leys, share this opinion in one way or another. According to this view, shame worked for our ancestors in their highly hierarchized communities, but in our current modern world it is detrimental for morality, because it promotes antisocial behaviour like avoiding others or lying to hide our mistakes from them, aggressive reactions against those who uncovered our shame, low self-esteem and depression, etc. Is it possible to save the intuition that shame has some ethical significance, while also accounting for non-moral instances of shame, and for its seemingly antisocial character?

The question of shame being social or private is often run in parallel with the question of shame's morality or immorality, although they are separate. Indeed, the former distinction often 
amounts only to a variation in the main element where the descriptions of the emotion are focused, with little emphasis on the ethical underpinnings of casting it as one or the other. But in many other accounts, the key strategy that authors adopt in order to defend shame's morality is precisely to argue that this emotion embodies private autonomy and not, as some others claim, social heteronomy. ${ }^{4}$ One of the most forceful recent vindications of shame as valuable for morality can be found in Deonna, Rodogno, and Teroni's book In Defence of Shame. Their strategy is precisely to challenge what they call "shame socialism" (7) and to propose instead a non-social account of how this emotion works. Their approach is one of the most explicit in challenging what they see as the deeply problematic social view of shame and offering an alternative non-social theory of this emotion. That is why, in addressing the issue of private shame, I have chosen to focus on their account.

In my view, the dichotomous opposition Deonna, Rodogno, and Teroni draw and their resistance to the idea that shame is essentially social arise from a very specific theory of the self and of morality, and a distinction between the public and the private realms purely in terms of ownership of values. But if we question those assumptions, the dichotomy dissolves. In my view, in order to do justice to the complex phenomenology of this emotion and to understand its ethical and ontological implications, we need to deploy different conceptions of the self, and the social and the private realms, and investigate how they are intertwined in shame. I agree with the view that shame is a relational emotion that reveals the self in its constitutive relationality (see Guenther, "Resisting Agamben"), and if the aim is defending it against views like Tangney's, and understanding its ethical role, we will never succeed by stylizing the phenomenon and leaving important aspects unexamined. 


\section{Shame: A First Attempt at a Description}

Let us now turn to the emotion itself. What does shame feel like? Its phenomenology is characterised by a feeling of exposure, inferiority, and vulnerability. Typical bodily manifestations include blushing, averting the gaze, adopting a collapsed bodily position, and so on: in shame, one feels smaller or wishes to become smaller and hide from view. Bernard Williams, in his conceptual genealogy, traced the original experience associated with shame in the Western tradition to that of being seen in the wrong circumstances by the wrong people, and more precisely, leaving the naked body exposed to the gaze of others. Therefore, the immediate reaction it triggers is that of covering oneself, hiding, or escaping (Williams 73). The key example, brilliantly analysed by David Velleman, comes from one of the foundational myths of Western culture, where shame is discovered precisely in this way, when Adam and Eve eat the forbidden fruit, at which point "the eyes of them both were opened, and they knew that they were naked; and they sewed fig leaves together, and made themselves aprons." in Adam and Eve, what makes them realize what they have done, is shame: their nakedness, their bodies become shameful, unfit to be exposed to each other's gaze, let alone God's. Starting from this paradigm of nakedness, shame would extend to other situations where we feel ridiculous, diminished in the eyes of another or simply exposed to her judgement, such as when a teenager is ashamed of being seen with his parents by his peers.

In developmental psychology, the appearance of full-blown shame is taken to be a manifestation of fully developed human self-consciousness, of a stage in which the child is already able to represent the minds of others and see herself from an external point of view: what Rochat calls "self-co-consciousness" or "co-consciousness" (61), and Reddy calls "self-otherconsciousness" (147-149), to distinguish it from a more basic, purely experiential, form of self- 
consciousness, where one is simply aware of oneself as distinct from the environment. This implies that shame is developmentally tied to the ability to be aware of the gazes of others upon us. From an evolutionary perspective shame is taken to descend from a proto-emotion in nonhuman animals that live in hierarchical social structures, where assuming and displaying inferiority can serve as a mechanism of appeasement and social cohesion when confronting a hierarchical superior (see Maibom). This mechanism would have gained complexity and depth in human groups, which are organized in more horizontal and collaborative ways that increase the importance of peers' favourable opinions, and thus it would have developed into the human emotion of shame. These structures can help us see why in shame we feel exposed, faulty, vulnerable, and inferior, and we feel the urge to disappear, to flee from the situation, away from vulnerability and danger.

Most accounts of shame agree in describing it, in general terms, as a distressing emotion, linked to a negative self-assessment that the subject performs upon him or herself due to the exposure of some defect, fault, or inadequacy to some ideal or norm. ${ }^{6}$ It can be due to actions or characteristics of the subject, or to things that happen to her, which for any reason make her feel inferior. ${ }^{7}$ Shame is the distressing feeling that we are at fault or inadequate. Virginia Woolf's short story "The New Dress," written with her famous stream of consciousness technique, provides a rich and illustrative example of an episode of shame as experienced from the firstperson perspective. This is the beginning:

Mabel had her first serious suspicion that something was wrong as she took her cloak off and Mrs. Barnet, while handing her the mirror and touching the brushes and thus drawing her attention, perhaps rather markedly, to all the appliances for tidying and improving hair, complexion, clothes, which existed on the dressing table, confirmed the suspicionthat it was not right, not quite right, which growing stronger as she went upstairs and springing at her, with conviction as she greeted Clarissa Dalloway, she went straight to the far end of the room, to a shaded corner where a looking-glass hung and looked. No! It 
was not right. And at once the misery which she always tried to hide, the profound dissatisfaction - the sense she had had, ever since she was a child, of being inferior to other people - set upon her, relentlessly, remorselessly, with an intensity which she could not beat off, as she would when she woke at night at home, by reading Borrow or Scott; for oh these men, oh these women, all were thinking - "What's Mabel wearing? What a fright she looks! What a hideous new dress!"- - their eyelids flickering as they came up and then their lids shutting rather tight. (49)

The fragment beautifully builds up to its emotional pitch by revealing Mabel's patterns of attention, how she focuses markedly on objects that she sees as highlighting her failure, how the gaze of others-Mrs. Barnett, Clarissa Dalloway—intensifies her self-consciousness, how finally looking at herself in the mirror takes her shame to its utmost intensity. Mabel Waring here is not naked, but this is clearly a case of her perceiving that she is being seen in the wrong circumstances by the wrong people: she immediately will go on to compare the approving look of the dressmaker in finishing her job, a look that made Mabel feel pretty and proud of her clothes, with the ironical remarks and critical looks of several guests at the party, which deepen her shame - an irony and disapproval that may only be in Mabel's overanxious imagination, or may have been grossly exaggerated by her; the stream of consciousness technique only allows us to access Mabel's impressions, sometimes mediated by the narrator's perspective through free indirect style. ${ }^{8}$ But for this emotion to appear, it does not make much of a difference whether the judgements are real or just imagined. Mabel feels exposed to judging gazes, looks at herself in the mirror and sees that something is not right, and an overwhelming feeling of inferiority takes hold of her. So the others' judgements and her own judgement are equally at play. However, the judgement that she is not only improperly dressed, but also completely devoid of elegance and grace, frightful and hideous, is not a cold one, it is embedded in her bitter feelings of inferiority, of littleness and degradedness. And there is also an impression of inexorability and inescapability: the shame is present from the moment when she takes her cloak off, but there is 
no possibility of running away from it and there is nowhere to hide. All these elements will become important as we move along. For the time being, let me just say that shame, as can be seen here, focuses on one's own self and embodies a negative self-assessment: the feeling of having a faulty self. But who is the main judge? Mabel herself or "oh these men, oh these women"? Is there a difference? And is the judging element really the crucial element?

\section{My Own Self as the Object of Shame}

Let us start by looking at the idea that shame is about the self of the person ashamed, that the self is its main object and focus. This is hardly controversial in the literature, although there are some blurry cases that I will deal with presently. But is Mabel not, rather, ashamed of her clothes? Shame is generally taken to have two objects, a direct one (the self ashamed) and an indirect one (the occasion for shame). In his Treatise of Human Nature, David Hume provides a helpful discussion of the way these two objects interact in self-conscious emotions when analysing pride and its opposite passion, which he calls "humility," and can be interpreted as a general term for negative emotions of this kind, notably including shame (278). He explains that these passions have an object to which they are directed, the self of the person ashamed, and a cause which excites them and without which they cannot appear (what I have called the indirect object of shame); they are about the self of the person ashamed but arise as a result of something else. ${ }^{9}$ So as we have just seen in the case of Mabel Waring, when she felt ashamed of her clothes at Mrs. Dalloway's party, she was ashamed of herself because she was improperly dressed.

The object to which shame is directed, then, is the self of the person ashamed. Even if it arises as a result of a certain action, we do not feel ashamed of the action itself, but of being the sort of person who can perform such an action. ${ }^{10}$ The thought would go: "How can I possibly be 
so clumsy, or so absent-minded, or so selfish, or so vain, or something else, to behave like this?" (see Maibom 568). Mabel's thought was not "I made a mistake," but "I am inferior." But is this always the case? Is it not common to feel ashamed of someone else, or even for someone else? Max Scheler, in his phenomenological analysis of this emotion, claims that shame is about "the individual self in general" (81), not specifically about the self of the person ashamed, and therefore we can feel genuine shame for other people in a non-vicarious way. ${ }^{11}$ I agree that shame can be felt for others in a genuine, non-vicarious fashion, but in my view, in these cases shame's object is still the self of the person ashamed, who feels, so to speak, exposed by proxy (but genuinely exposed). What this calls into question is the idea of an encapsulated, autarchic self with clear self-generated boundaries and limits. It is possible to feel exposed in somebody else's exposure. There are "beings whose self-revelations reveal oneself," as can be the case of close family members or intimate friends, and there are also situations that can create ties of a more temporary nature, but are still capable of making one feel revealed in somebody else's selfrevelation (S. Cavell 286).

In his analysis of pride and humility, Hume devised a structure that can help understand this. He talks about a double relation of impressions and ideas. The self would be an idea, about which we can feel the passion of humility (or shame). But in order for it to arise, there must be a second idea, what Hume calls a cause and I, following the current terminology in use, have called an occasion for shame (or, also, its indirect object). This can be a feature, an action, an object, anything that is closely connected to me: the crucial point is not what type of thing or event it is, but the fact that it is closely connected to me. ${ }^{12}$ The cause has certain qualities that produce certain impressions on me: if such impressions are agreeable, I will feel proud; if disagreeable, I will feel humbled. So, because object and cause (self and occasion) are connected 
at the level of ideas, there is a parallel connection between the impressions produced by the cause and the emotion felt by the subject: unpleasant impressions will correspond to the unpleasant emotion of humility, and vice versa for pride. If any of those elements is missing, the emotion will not arise: a disagreeable object that is unrelated to me will not give rise to shame, and neither will an object that is connected to me but not disagreeable. According to that structure, someone else, who was connected to me in the relevant sense, could obviously be a cause —or an indirect object—of my shame, could leave me exposed in the relevant sense.

In this structure, the flexible nature of what a relevant connection to oneself may be starts pointing toward a crucial issue: that the kind of selfhood at stake in shame is not an encapsulated, self-sufficient self with clear boundaries or delimitations. There can be little question that what causes the feeling of exposure does not necessarily have to be originated in the individual who experiences shame. Family members, as Stanley Cavell remarks, but also friends, or even simply people from the same country, can be a source of shame (think about travelling abroad and seeing a group of your fellow citizens doing something outrageous). But sharing a trait or simply a situation with someone might be enough: being present at a dinner party where an obnoxious guest unwittingly offends the host, for instance. ${ }^{13}$ If one felt shame in this situation, it would be what in Spanish is called vergüenza ajena (an expression that literally says that one is feeling somebody else's shame). This can be seen as a special sort of preventive shame, pudor or modesty, through which I isolate myself from the shameful feature or situation and reassure myself of my superiority. I simultaneously identify and dis-identify myself with the shameful subject, and reassure myself that, because I feel shame in that situation, I am morally superior, as in the case reported by Boris Cyrulnik of a Polish Jew who survived the Warsaw ghetto, and many years later, in a trip to Israel, felt ashamed of the treatment Palestinians received there, 
because it reminded him of Warsaw (29-30). Cyrulnik claims that this man was actually proud of his moral shame, which showed he was not a criminal, because he felt ashamed of the possibility of being associated with those who were abusing others. These cases introduce a whole other set of issues that I cannot deal with here, but I mention them because they highlight the complexity of pinning down the self of shame: a self that can feel revealed in others' self-revelations.

\section{Social Shame Versus Private Shame}

But what is the source of the norm according to which the subject judges herself in shame? Generally, it is taken to be a social source: the negative judgement of others. Shame would be anxiety about those judgements (extreme and overwhelming anxiety in Mabel Waring's case). However, shame can appear as well in the absence of actual observers. Such was the case, for instance, for Anna Karenina, alone in the train from Moscow to St. Petersburg, not daring to admit, even to herself, that a respectable and decent married woman like herself could have fallen in love with a dashing young officer like Vronksy; such was Phaedra's case, again a respectable wife burning with desire for a dashing young man, her stepson Hippolytus, and consumed in silent shame about it, long before anyone else knew about it or had the chance to give her indecent advice and reveal the secret to Hippolytus, as her nurse eventually did. ${ }^{14}$ Moreover, shame is often felt retrospectively, when we remember situations that, at the time and in the presence of witnesses, may not have seemed particularly discomforting. And even if they did, what I call retrospective shame is not the same as remembered shame, ${ }^{15}$ although shame can also be remembered, of course. Retrospective shame is real shame, felt with full intensity at the moment of remembering it: it is not the reminiscence of an emotion, but the emotion itself. Peter Goldie has a telling example of a man who gets drunk at an office party, climbs on top of a table, 
and starts singing "Love is Like a Butterfly" at the top of his voice (38-39). At the time, in his drunkenness, he may have only thought about what a wonderful song this was, how merry and happy everyone looked, and how much they seemed to be enjoying his performance. But when he remembers the episode the next morning, he will see the situation in a different light; he will realise that his colleagues were laughing at him and not with him, and only then feel ashamed of himself.

The cases in which we feel shame in solitude, when nobody is seeing us, are explained by those who propound social accounts of shame as caused by the internalization of an audience, of the gaze of the other upon me, as in Sartre's famous example of the voyeur who is looking through a keyhole, and starts feeling ashamed when he hears a noise that reminds him that someone may see him behave so indecently (Sartre 286). ${ }^{16}$ Richard Wollheim's psychoanalytic account explains shame as caused by the introjection of an external authority figure, which becomes an internal "criticising agency" that judges and censors the ego. ${ }^{17}$ Shame for social theorists - admittedly, the majority of shame theorists-is essentially a consciousness of exposure to the censoring gaze of another. In shame, I would see that I am being seen, and I would judge myself according to that external gaze, as Mabel Waring did. ${ }^{18}$

But some other cases are very unclear, and seem to indicate a difference between the actual audience and the "criticising agency" that causes the shame. For example, if a teetotaller who thought that drinking was a sin, was seen drinking a glass of champagne at a party, probably none of the other guests would care about it in the slightest, or they might even celebrate it, but he would still feel shame. ${ }^{19}$ A converse example would be provided by Diogenes the Cynic, who famously lived in extreme poverty in a tub in Athens' marketplace, and didn't feel ashamed of any of the provocative things he did to shock Athenians into thinking, while mostly everyone 
else thought he should feel shame for leading such a life. Those are two examples in which social evaluations - the indictments coming from the social environment of the subject, from the people he is surrounded by-do not seem to have an effect on the subject's negative self-assessment. Both cases are of course very different, in that the teetotaller is completely disconnected from the conventions applied by other guests of the party, whereas Diogenes is not disconnected from those applied by his fellow citizens. Indeed, his shamelessness is informed by them: he criticises the conventions from the inside, and is by no means oblivious of them. But both examples underscore the fact that other people's judgements of oneself are independent from one's own self-assessment and need not determine it. ${ }^{20}$

Can an internalized audience account for these examples? In order to fit them into the previous picture of shame as social, shame as elicited by the gaze of the other, one would have to say that the relevant other capable of making the subject feel shame in such cases is not a representative of the society where these men happen to be, but an internalized spectator whose opinion they care about, someone embodying a code they can respect: a parent, a peer, etc. ${ }^{21}$ However, this internalized observer is not always clearly identifiable; the question "who is observing and judging me?" is often very hard or even impossible to answer, or has only one obvious answer: myself (see Deonna, Rodogno, and Teroni 30-32). Indeed, Diogenes' endeavour can be construed as directed toward recognizing no judge but himself. If this is so, would it not be more natural, and more faithful to the phenomenology of shame, to say that $I$ am always the judge, that the standards at play in this self-assessment are my standards?

This is what Deonna, Rodogno, and Teroni ask themselves. In their recent book In Defence of Shame, they set out to argue against what they call the two current "dogmas" about shame: that it is social, provoked by the gazes and judgements of others, and that it is "ugly," 
that it fosters maladaptive and immoral action tendencies. In their view, the often referred-to phenomenology of the gaze of another, of the internalized audience that observes us, does not appear clearly in most cases; it represents, rather, a metaphor through which we think retrospectively about shame (Deonna, Rodogno, and Teroni, Part One). The fact that the values developmentally come from social sources is also irrelevant for qualifying it as social, as that is also the case for all other moral emotions and therefore could not act as a distinctive feature of shame.

Their analysis of this emotion is based on a concept of the self and of identity with obvious (and declared) Kantian overtones, which bears some important relations to Harry Frankfurt's. According to him, the core self is constituted by "what we care about," by the profound values and ideals that actually shape our will and guide our actions, and which we moreover make our own, appropriate as part of ourselves. Frankfurt thinks we shape our identities by selecting among the materials of our psychical life, and appropriating some of them rather than others through action; so, in his view, self, identity, and agency are indissolubly tied.

Deonna, Rodogno, and Teroni also think about identity in terms of values we care about. They stress the fact that, for these values to be a part of one's identity, it is not enough to deem them positive or important in general; one has to want to exemplify and reflect them in one's life (see Chapter 4). One can value good art, for example, and think it important for society that there are good artists in the world, without wanting to be an artist oneself. The identity-relevant value here would be having discernment for good art (recognizing a good piece when seeing it), whereas artistic creativity would be valued positively, without being identity-relevant. The distinction is crucial, because for Deonna, Rodogno, and Teroni shame arises from the perception of an incapacity to exemplify a value one identifies with and cares to reflect in one's 
life (94-98). This is their definition: "In shame, we apprehend a trait or an action of ours, which we take to exemplify the polar opposite of a self-relevant value, as indicating our incapacity to exemplify this self-relevant value even to a minimal degree" (97). ${ }^{22}$ Thus, the person in my example could feel ashamed of making a terribly bad artistic judgement, but not of being unable to produce a work of art. According to Deonna, Rodogno, and Teroni, the frequent interpretation of shame as social comes from the crucial importance that we, as social beings, attach to others in our lives, and to our relations with them. But shame is not caused by sensitiveness to their judgement: shame is a private affair of living up to the standards I identify with.

\section{Should We See The Social, The Private and their Relation in these Terms?}

Deonna, Rodogno, and Teroni rightly highlight the fact that characterizing shame as a "social" emotion can be misleading, depending on how we interpret the adjective. There is a sense in which all so-called moral emotions - such as shame, guilt, contempt, pride, resentment, gratitude, compassion, and so on - and many of the non-moral ones too, are social, because they arise and are only conceivable in a social, relational context; they can only appear and make sense in our relations to other agents, and if we feel them about things or beings that cannot reasonably be conceived as agents, it is only because we personalize them or attribute to them agential capabilities. In this sense, shame can be nothing but social. But they don't dispute this claim, which in any case is not so interesting for them, because it would not distinguish shame from any of those other emotions. ${ }^{23}$

But a question needs to be asked in this context: what do "private" and "social" mean here? When they argue against the social conception of shame, Deonna, Rodogno, and Teroni (32-37) identify three stronger and controversial strands of this claim: i) shame as heteronomous, 
i.e., embodying values that do not belong to the ashamed subject; ii) shame as involving "an evaluation in terms of one's appearance vis-à-vis an audience" (34); iii) shame as the result of adopting an external perspective on ourselves. They defend instead the thesis that shame is about my values, about what I am and not what I appear to be, and that in shame I am my own judge and need not adopt anybody else's perspective. Many of their criticisms, I find, are warranted. Shame does go deeper than appearances and public image: embarrassment would be the related emotion that always requires an audience and concerns our appearances before it. And it can't be right to think that in shame we simply judge ourselves according to social evaluations, that we uncritically endorse an external verdict on ourselves. The examples I mentioned before of the teetotaller and Diogenes the Cynic tell against this: we can and we do challenge the external criteria of the shameful (see Hutchinson). If we were always ashamed of what the community deems shameful, there would be no room to distinguish between shame and humiliation, for instance; but there clearly is (see "Resisting Agamben" 61-62). In English "humiliation" often simply refers to an intense form of shame. But it can mean something very different, it can refer to an action, or to the feeling caused by it, and in this sense it has a much more external and imposed character: Guenther depicts it as a feeling that we are being singled out as abject and unworthy, and violently rejected. An act of humiliation may make us feel ashamed, but it very often does not; rather, it makes us react with anger or indignation. So shame seems to involve our own evaluations more prominently than external ones, or at least more prominently than some accounts seem to concede. So far, so good.

But does this mean that shame is non-social? Is "heteronomous" the same as "social?" Is "autonomous" the same as "non-social" or "private?" How is the private character of shame to be understood? For Deonna, Rodogno, and Teroni, it is understood simply in terms of value 
ownership. As we have seen, when they flesh out their account of shame, they base it on a conception of the self as the set of my own identity-relevant values, the values, norms, ideals and commitments by which I define myself. And my judging myself simply amounts to a comparison between my ideals and norms and their more or less unsuccessful realisations. All in all, this seems to me a very superficial sense of what it means for shame to be non-social, or private, which is reduced to a matter of value ownership: my own values versus society's values. It is simply a question of tracing a boundary and deciding which items belong inside and which outside. But values and norms, anything that has normative character, are essentially public: they are essentially sharable and, in that sense, not private at all. For a norm to be a norm, it has to be generalizable to a certain degree, it has to aspire to apply to any individual of the same characteristics in the same circumstances - where "same" is taken in the sense of qualitative, not numerical, identity. Would a norm still be a norm if it were only applicable to the same numerically identical individual at one specific point in time? Normativity implies generalizability and sharability, and it only allows for a very superficial sense of the non-social character of this emotion. In their account, it all happens in terms of mechanisms that are public: norms, ideals, judgement. The judgement I make of myself in shame could be made by someone else from a different perspective, if she knew what my identity-relevant values were, and it would not change in any way. Non-social, then, means autonomous.

This theory, however, does not account for the special self-relation that we find in shame. Selfhood and the sense of self cannot be explained merely in terms of a set of features whereby I define myself from a purely third-person point of view, as I define an object. Selfhood is what makes me distinguish self from world from a first-person perspective, a difference I feel acutely in shame. But the account of the self of shame as a set of values makes it look exactly like the set 
of features of an object. There is nothing characteristically intimate, private, or first-personal in the assessment that I am not able to exemplify a self-relevant value. Shame is reduced to a judgement anyone could make from a third-person perspective. But, as I pointed out earlier, there is something distinctively first-personal about shame, a surprising revelation of what I am. Lévinas powerfully describes it as "being riveted to oneself" (64) and Sartre talks about "being irremediably what I always was," a sense of being trapped in what I am, not because I have committed a mistake, but simply because I have discovered that I am an object of observation and judgement and there is a dimension of my being that entirely escapes me (312). This intimate self-relation of discovering an aspect of my being, this first-personal experience of feeling trapped in what I am, the experience so powerfully described by Virginia Woolf, cannot be accounted for just in terms of judgement.

Phenomenology can offer a very different, deeper, and more interesting account of what the truly private character of shame may be. It has to do with a crucial feature of emotion, which is completely absent from Deonna, Rodogno, and Teroni's account: the felt experiential character of emotion in general and shame in particular, and the relation of oneself to oneself that is established in shame. These views are based on a conception of the self that differs essentially from the one they adopt. Drawing from classic phenomenology, Dan Zahavi has been defending for some years a theory of the minimal, experiential self, which in his view is the most basic form of selfhood. It is based on the first-personal character of experience, on the fact that all experiences require an experiencer, that they are experiences for someone:

An informative way of characterizing the self might consequently be as a ubiquitous dimension of first-personal givenness in the multitude of changing experiences. This is not meant to imply that genuine self-experience requires the experience of something invariant or identical ... This for-me-ness or mineness, ... is not a quality like green, sweet or hard. It doesn't refer to a specific experiential content, to a specific what, nor 
does it refer to the diachronic or synchronic sum of such content, or to some other relation that might obtain between the contents in question. Rather, it refers to the distinct givenness or how of experience. It refers to the first-personal presence of experience. ... It refers to the fact that the experiences I am living through are given differently (but not necessarily better) to me than to anybody else. (Zahavi 556-57)

Zahavi recognises that this experiential self does not account for the full complexity of human selfhood (Zahavi, Subjectivity and Selfhood 128-132), and that the self concerned in shame involves more than this basic experiential self, but this view emphasises a whole set of questions that are ignored in an account of emotions in terms of judgements and of self in terms of values. "Private" here takes a completely different meaning: that of self-experience.

Emmanuel Lévinas goes deeper into the self of shame in his suggestive analysis of this emotion. As I already pointed out, in his On Escape, he links shame to the impossibility of escaping from oneself, from what one is, the impossibility of ceasing to be what I am:

[Shame] is the representation we form of ourselves as diminished beings with which we are pained to identify. Yet shame's whole intensity ... consists precisely in our inability not to identify with this being who is already foreign to us and whose motives for acting we can no longer comprehend ... (63)

But here, at the beginning of his discussion, he still talks about motives for acting: we are still in the third-personal realm of the conventional and the normative, in the realm of judgement. Shame, Lévinas goes on to say, stressing the private side,

is that one seeks to hide from the others, but also from oneself ... What appears in shame is thus precisely the fact of being riveted to oneself, the radical impossibility of fleeing oneself to hide from oneself, the unalterably binding presence of the I to itself. (64)

This strong urge to escape while being riveted is what Lévinas finds more characteristic of the phenomenology of shame. The image is powerful and compelling: in shame, I want to disappear and sink through the ground, but I become painfully aware that this is impossible, that I am there, 
that I can never escape from my own being. And this is something that can only make sense from the first-person perspective.

The feeling was clearly described in the Virginia Woolf passage I quoted before: the inexorableness and inescapability of Mabel's shame are obvious from the start, and they become even more obvious as the story progresses and deepens the description of her shame. Mabel is trapped with no escape from herself: leaving the party will not do, and it does not do, when she leaves at the end of the story. It simply makes more conspicuous the fact that her self is shameful. From the moment she takes off her coat and the suspicion that "something is not right" takes hold of her, she is naked in front of herself. Her presence to herself is inescapable, and any effort to escape makes this more evident. There is nowhere to go where our being will not follow. We are riveted to ourselves. "It is ... our intimacy, that is, our presence to ourselves, that is shameful" (Lévinas 65).

Whatever the source of any judgement of inadequacy, whatever its causes or the norms that govern it, the genuinely private side of shame is this self-relation. This is a discovery nobody else could make but oneself, a discovery that is no such discovery for an external observer. Nobody but myself could feel riveted when realizing that I am this being, this body, this person; nobody else is riveted to it. Shame involves a sense of alienation and simultaneously an impossibility to be other, an indissoluble self-relation. But how do we come to see ourselves as "this being who is already foreign to us"? How does one achieve the capacity to see oneself as "this being"? 


\section{Sociality or Intersubjectivity?}

As Zahavi repeatedly claims, the experiential self is just a minimal sort of selfhood, which can be attributed to beings with no high-level form of self-consciousness, beings that presumably are incapable of the mode of self-relation that Lévinas describes. So there is more to the self of shame than the first-personal character of experience: it requires self-otherconsciousness. Some developmental psychologists (see, for instance Rochat) — as well as Hegel and many philosophers who follow him in this - maintain that we become fully self-conscious subjects, i.e., self-other-conscious subjects (Reddy) or people able to say "I" (M. Cavell), by living and interacting with others. The interest we have from infancy onwards in commanding and keeping other people's attention and care pushes us to try to see what others have in mind, thus learning that there are other perspectives on the world. When we, in our effort to command their attention, look at ourselves from the other's perspective, we realize that we have an outside and thus become divided subjects who can see themselves as selves. This process of becoming an object to oneself would never be possible in isolation from other subjects, with no connection whatsoever to a world of people, and there is ample evidence of the destructive effects that isolation has upon our sense of self: by losing intersubjective relations, we lose ourselves as well-and I use "lose" in a non-metaphorical sense here. ${ }^{24}$ This process of becoming self-otherconscious is essentially tied to shame.

Sartre's analysis of shame in Being and Nothingness can help further illuminate these issues. ${ }^{25}$ Let us go back to his example of the peeping Tom crouching at the keyhole I mentioned earlier. The fact that he is aware that someone else may see him and disapprove of his voyeuristic conduct is enough to trigger shame. Sartre does not speak about an internalized audience, but he argues that my awareness of the existence of the other and her external 
perspective upon me is what makes me realize I have a skin, an exterior that can be seen from the outside, from a point of view which is not mine and over which I have no control. That is what makes me a divided self-conscious subject, who can see herself as an object. This perspective could never be achieved in solitude: the only way I have of realizing that I can be an object of judgement, and therefore also become aware that I have my own subjective perspective, is to see that I am being seen. ${ }^{26}$ And that is the basic structure of shame, which ultimately is nothing but an intensified form of self-other-consciousness. In Sartre's account, there is no internalized observer, but the other's perspective is essential and always already implied in the structure that underlies self-other-consciousness and shame. This does not mean that in order to feel shame, we need to adopt someone else's particular perspective, but we do need this poignant awareness that we have an outside that can be and is judged from particular perspectives other than our own.

Shame attests to the awareness that our self can be and is perceived and judged from external perspectives, but not the precise actual judgement a particular surrounding context makes. For one can be delusional and represent to oneself a world that in no way resembles reality, or choose as one's reference point a world that does not correspond with the surroundings at the moment, like the teetotaller in our example. And in any case we all perceive the world through our own sensibilities and represent it accordingly, a feature that was salient in the passage from Virginia Woolf: Mabel's eccentric new dress has probably provoked some amusement at the party, but surely not the unforgiving disapproval she imagines. In any case, shame requires an awareness of this judging external perspective. Perhaps it would be more appropriate to cash this out in terms of intersubjectivity, of being always in a direct relation to another, rather than in terms of sociality, if "sociality" has an excessive ring of conventions, of 
rules and dynamics within a collective, and seems to take us in the direction of uncritically submitting to them.

Conventions do influence quite strongly my sense of self, which is affected and partially determined from the outside as well, by factors such as gender, race, nationality, my place in society, my role in my family, my professional status, and so on. But, most importantly, by how the other in front of me sees me. This does not mean that I uncritically accept her judgement on myself, but that I am aware of it and take it into account. And I take it into account always, even if to dismiss it as irrelevant or contemptible. In such a case, it is the particular judgement of this particular other I reject, not the fact that I am exposed to others and partially-but cruciallydependent on them. These conventions are made possible by relationality, which is constitutive of self-other-consciousness. It is the structure, not the conventions, that is crucial. In this nonconventional sense, the public is as essential to shame as the private, because it is equally essentially constitutive of human selfhood, and shame attests to this.

\section{Conclusions}

In this paper, I have argued against the dichotomous opposition between social and nonsocial shame, and I have tried to show that the terms in which the opposition is framed are inadequate. The debate about the autonomy or heteronomy of shame leaves crucial aspects unexamined. Shame involves a very private self-relation that reveals the self to itself, and at the same time prefigures self-other-consciousness and intersubjectivity. The change of perspective that this self-revelation entails links the subject to a world of others. Shame, thus, can only appear in the intermediate space between the social and the private, and it would not be possible 
in the absence of one of them. So, far from being dichotomous, the social and the private are two essential aspects of shame, two inseparable sides of the same coin.

How does this affect the answer to the ethical question, which was my background question? Does it help make progress towards an answer? It does, by reorienting our analysis towards more fundamental issues. First, if the self of shame is not a set of self-relevant values, the ethical role of shame cannot be obviously cashed out in terms of its being an expression of autonomy. This means that we probably need to dismiss shame as morally irrelevant, or think of it in a framework that does not require emotions to be turned into mere judgements for them to have some ethical significance. Second, the foregoing discussion highlights the link between shame and self-other-consciousness, the idea that the dual perspective (first- and third-personal) on the self present in shame entails some form of awareness of a world of others, that some form of self-other-consciousness is at the heart of the capacity for shame. Some authors go so far as to situate it at a constitutive level. Sartre can be read as saying that full-fledged human selfconsciousness is constituted by shame. Rochat seems to be arguing in this direction. And Agamben, precisely, finds in shame the cornerstone of a fundamental form of ethics that comes before good and evil (see Agamben 20). Is that so? Is shame among the constitutive elements of moral personhood? Does it come before it? How do they connect? These are all open questions, which can only be explored by taking into account the full complexity of the self of shame. 


\section{Notes}

* This paper has been prepared with the generous support of the Research Projects on "Identity, Memory and Experience" (FFI2009-09049, Head: Prof. Dr. Carlos Thiebaut) and "Crossroads of Subjectivity: Experience, Memory and Imagination” (FFI2012-32033, Head: Prof. Dr. Antonio Gómez), funded by the Spanish Subsecretariat for Research, Development and Innovation. I am exceedingly grateful to Antonio Gómez Ramos and Dan Zahavi for their invaluable comments. Thanks are also due to the audiences of several seminars at Universidad Carlos III (Madrid), the University of Manchester, and the Centre for Subjectivity Research (Copenhagen), where I presented preliminary versions of this paper.

${ }^{1}$ A distinction - that can be traced back at least to Hegel - is often made in moral philosophy between ethics and morality, where "morality" is connected to a more Kantian picture, focusing on concerns about duty and autonomy, while "ethics" is associated with a more Aristotelian picture, focusing on eudemonistic concerns and virtue. It is not always possible to keep this distinction in a very systematic way, and indeed, in many situations, such as these initial paragraphs, one welcomes the ambiguity: one wants a term that can cover both meanings. Generally speaking, whenever possible, I will tend to use the term ethics in a broad sense, hoping it to cover as much ground as possible, and I will reserve the term morality in the narrower sense, to mean duty ethics. See Bernard Williams' discussion of this issue, especially Chapter 1.

2 This point is roughly the same one that Bernard Williams was making back in 1993 in Shame and Necessity, but it is still valid to a very large extent.

${ }^{3}$ It should be noted that, in their book, they do not apply the label "private" to their own account. I hope that my use of that word throughout the paper does not misrepresent their views.

${ }^{4}$ The issue of autonomy and heteronomy is not identical with the issue of the social versus private character of this emotion, as I will argue later on, but it seems to have been conflated in some views. At this stage I don't yet need to question this assumption.

${ }^{5}$ Genesis 3, 7-8 (King James Version). See David Velleman's interesting discussion of this passage. I won't go into an analysis of Genesis here, but in my view it is no coincidence that the birth of conscience in the Bible is linked to shame.

6 This definition, which is relatively tentative and does not aspire to be exhaustive, is based on the definitions and the literature reviews provided in two papers: Maibom; Teroni and J. A. Deonna.

${ }^{7}$ The discussion of shame in the context of morality usually includes a comparison with guilt. The fact that shame can be due to things that are completely out of the scope of our control, like physical traits we are born with or things that happen to us, is one of the reasons why the defenders of guilt as the superior moral emotion have argued that shame is less moral than guilt. 
${ }^{8}$ For more on free indirect style as a combination of narrator and character's perspective, and how it features in the ways we see ourselves, see Goldie (28-32).

${ }^{9}$ I use the word "passions" here, because it is the term that Hume employs, but I take it to be a synonym of "emotions." The word emotion was not very common until the nineteenth century, when scientists like Darwin and many others, including philosophers, started to adopt it generally as a more scientific and aseptic term to replace the traditional terms "passions" and "affects," which were charged with religious and moral connotations. See Thomas Dixon's excellent study of the history of these terms.

10 When shame is unequivocally moral, this is taken to be the crucial phenomenological difference between shame and guilt: guilt attaches to my action, shame attaches to my own self.

${ }^{11}$ For a detailed account of Scheler's arguments, see León.

12 "Closely" here means that there must be something about this object or situation that can have an impact on my sense of self. There has to be what Gabriele Taylor (28-32) calls a relationship of belonging, a relationship that allows for identification: for whatever reason, I have to perceive that my identity, in the sense of who I am, is at stake or affected in this situation. Or, to put it in the terms I will be favouring later on, something has to make me experience my presence to myself. Shame-inducing objects and situations will vary depending on culture, character, personal values and so on.

${ }^{13}$ I owe this example to Peter Goldie.

${ }^{14}$ Anna Karenina: Tolstoy, Part I, Ch. 24. Phaedra: Euripides, Hippolytus, lines 373-432.

15 Rafael Sánchez Ferlosio (30), for example, acknowledges this: el escozor de la vergüenza podemos volver a sentirlo una y otra vez, incluso incrementado, estando a solas, con sólo rememorar imaginariamente la situación social originaria de la vergüenza padecida ("the sting of shame can be felt time and again, even intensified, when we are on our own, merely by evoking in our imagination the original social situation of shame endured," my translation).

${ }^{16}$ For other interesting formulations of this hypothesis, see Williams and Maibom.

${ }^{17}$ And guilt too, of course; he sees no relevant difference in this respect. See Wollheim, Lecture Three.

${ }^{18}$ I am grateful to Antonio Gómez Ramos for this Sartrean formulation, which so neatly captures the reciprocity of shame.

${ }^{19}$ I am grateful to Peter Goldie for suggesting these examples and for pressing me to question the pertinence of the private versus social dichotomy. 
20 See Phil Hutchinson's discussion of different kinds of shamelessness, particularly of the case of Diogenes (105-107). I am grateful to a PhaenEx anonymous reviewer for pressing me to clarify the differences between those two cases.

${ }^{21}$ See Bernard Williams' discussion of this issue (84-85).

${ }^{22}$ For them, the difference between shame and frustration or self-disappointment lies in the fact that, in shame, one exemplifies the polar opposite of the identity-relevant value, and interprets this as an incapacity to exemplify, even minimally, the said value. In their view, other forms of self-disappointment are less acute, because we don't perceive them as indicating this incapacity. They recognise degrees of exemplification and hierarchies of value importance, which allows them to account for differences in intensity of shame episodes.

${ }^{23}$ It is interesting to note, however, that when they put Richard Wollheim on the side of social shame theorists, they fail to mention that for Wollheim, this is not a distinctive feature of shame: guilt for him is as social, and as heteronomous, as shame. Indeed, in Wollheim's psychoanalytic perspective, morality itself is heteronomous: the superego is always conceived as an introjected external force trying to impose on the ego. Both shame and guilt arise in his view as a result of the "criticizing agency's" reproaches. In Wollheim's view, there is no contradiction between morality and heteronomy.

${ }^{24}$ See the website Solitary confinement for a source of information on the depersonalizing and other effects of this kind of punishment. I am grateful to Lisa Guenther for drawing my attention to this topic and refer the reader to her forthcoming book Social Death and Its Afterlives.

25 I am heavily indebted to Lisa Guenther and her reading of Sartre (see "Shame and the Temporality of Social Life").

${ }^{26}$ Does this take us back to the phenomenology of the gaze of another after accepting the objections to it? The pull of such ways of thinking and speaking is great, probably for good reasons. I hope that the use of the verb "to see" here can be accepted as widely metaphorical (indeed, it is often a synonym of understand or interpret). I do not mean to imply that we always have to actually represent ourselves visually as we would appear from an external viewpoint. The external perspective simply implies that we can be the object of someone else's judgements or perceptions of various kinds. 


\section{Works Cited}

Agamben, Giorgio. Remnants of Auschwitz. New York: Zone Books, 1999.

Benedict, Ruth. The Chrysanthemum and the Sword: Patterns of Japanese Culture. New York: Houghton Mifflin Harcourt, 2005.

Burnyeat, Myles. "Aristotle on Learning to Be Good." Essays on Aristotle's Ethics. Ed. Amelie Oksenberg Rorty. Berkeley: University of California Press, 1980. 69-92.

Cavell, Marcia. Becoming a Subject: Reflections in Philosophy And Psychoanalysis. Oxford: Clarendon Press, 2006.

Cavell, Stanley. "The Avoidance of Love: A Reading of King Lear." Must We Mean What We Say? A Book of Essays. Cambridge: Cambridge University Press, 1995. 267-353.

Cyrulnik, Boris. Mourir de dire. La honte. Paris: Odile Jacob, 2010.

Deonna, Julien, Raffaele Rodogno, and Fabrice Teroni. In Defense of Shame: The Faces of an Emotion. New York: Oxford University Press, 2011.

Dixon, Thomas. From Passions to Emotions: The Creation of a Secular Psychological Category. Cambridge: Cambridge University Press, 2003.

Euripides. The Complete Greek Tragedies, Volume 3: Euripides. Eds. David Grene \& Richmond Lattimore. Chicago: University of Chicago Press, 1992.

Ferlosio, Rafael Sánchez. El alma y la vergüenza. Barcelona: Destino, 2000.

Frankfurt, Harry G. The Importance of What We Care About: Philosophical Essays. Cambridge: Cambridge University Press, 1988.

Goldie, Peter. The Mess Inside: Narrative, Emotion, and the Mind. Oxford: Oxford University Press, 2012.

Guenther, Lisa. "Resisting Agamben: The biopolitics of shame and humiliation." Philosophy \& Social Criticism 38.1 (2012): 59-79.

—. "Shame and the Temporality of Social Life." Continental Philosophy Review 44.1 (2011): 23-39.

-. Social Death and Its Afterlives: A Phenomenological Critique of Solitary Confinement. (Minnesota University Press, forthcoming). 
Hume, David. A Treatise of Human Nature. 2nd ed. Eds. L. A. Selby-Bigge \& P. H. Nidditch. Oxford: Claredon Press, 1978.

Hutchinson, Phil. "Facing Atrocity: Shame and Its Absence." Passions In Context: International Journal for the History and Theory of Emotions (2011): 93-117.

León, Felipe. "Shame and Selfhood.” Phänomenologische Forschungen (forthcoming, 2013).

Lévinas, Emmanuel. On Escape. Trans. Bettina Bergo. Stanford: Stanford University Press, 2003.

Leys, Ruth. From Guilt to Shame: Auschwitz and After. Princeton: Princeton University Press, 2009.

Maibom, Heidi L. "The Descent of Shame.” Philosophy and Phenomenological Research 80.3 (2010): 566-594.

Reddy, Vasudevi. How Infants Know Minds. Cambridge, MA: Harvard University Press, 2008.

Rochat, Philippe. Others in Mind: Social Origins of Self-Consciousness. 1st ed. Cambridge: Cambridge University Press, 2009.

Sartre, Jean-Paul. Being and Nothingness. Trans. Hazel Barnes. New York: Routledge, 2003.

Scheler, Max. "Über Scham und Schamgefühl." Schriften aus dem Nachlass, Bd. 1 : Zur Ethik und Erkenntnislehre. Vol. 1. Bern: A. Francke AG Verlag, 1957. 65-154.

Shalev, Sharon. Solitary Confinement. Solitary Confinement, 2012. Web. 2 Jul. 2012.

Tangney, June Price. "The Self-Conscious Emotions: Shame, Guilt, Embarrassment and Pride." Handbook of Cognition and Emotion. Eds. Tim Dagleish \& Mick J. Power. Chichester, UK: John Wiley \& Sons, Ltd, 2005. 541-568. Web. 16 Mar. 2012.

Taylor, Gabriele. Pride, Shame, and Guilt: Emotions of Self-Assessment. Oxford: Clarendon Press, 1985.

Teroni, Fabrice, and Julien A Deonna. "Differentiating Shame from Guilt." Consciousness and Cognition 17.3 (2008): 725-740. Web. 5 Dec. 2011.

Tolstoy, Leo. Anna Karenina. Trans. Richard Pevear \& Larissa Volokhonsky. London: Penguin Classics, 2004.

Van Heerden, Adriaan. "Disgrace, Desire, and the Dark Side of the New South Africa." J. M. Coetzee and Ethics: Philosophical Perspectives on Literature. Eds. Anton Leist \& Peter Singer. New York: Columbia University Press, 2010. 43-63. 
Velleman, J. David. “The Genesis of Shame.” Philosophy \& Public Affairs 30.1 (2001): 27-52.

Williams, Bernard. Shame and Necessity. 2nd ed. Berkeley: University of California Press, 2008.

Wollheim, Richard. On the Emotions. New Haven: Yale University Press, 1999.

Woolf, Virginia. "The New Dress." A Haunted House, and Other Short Stories. London: The Hogarth Press, 1973. 49-58.

Zahavi, Dan. "Is the Self a Social Construct?" Inquiry 52.6 (2009): 551-573.

—. Subjectivity and Selfhood: Investigating the First-Person Perspective. Cambridge, MA: MIT Press, 2005.

—. "Self, Consciousness and Shame." The Oxford Handbook of Contemporary Phenomenology. Ed. Dan Zahavi. Oxford: Oxford University Press, 2013. 